\title{
Complete genome sequencing and analysis of endophytic Sphingomonas sp. LK11 and its potential in plant growth
}

\author{
Sajjad Asaf ${ }^{1} \cdot$ Abdul Latif Khan $^{1} \cdot$ Muhammad Aaqil Khan ${ }^{2} \cdot$ Ahmed Al-Harrasi $^{1} \cdot$ In-Jung Lee ${ }^{2}$
}

Received: 18 May 2018 / Accepted: 10 August 2018 / Published online: 28 August 2018

(c) The Author(s) 2018

\begin{abstract}
Our study aimed to elucidate the plant growth-promoting characteristics and the structure and composition of Sphingomonas sp. LK11 genome using the single molecule real-time (SMRT) sequencing technology of Pacific Biosciences. The results revealed that LK11 produces different types of gibberellins (GAs) in pure culture and significantly improves soybean plant growth by influencing endogenous GAs compared with non-inoculated control plants. Detailed genomic analyses revealed that the Sphingomonas sp. LK11 genome consists of a circular chromosome (3.78 Mbp; $66.2 \% \mathrm{G}+\mathrm{C}$ content) and two circular plasmids (122,975 bps and 34,160 bps; 63 and 65\% G+C content, respectively). Annotation showed that the LK11 genome consists of 3656 protein-coding genes, 59 tRNAs, and 4 complete rRNA operons. Functional analyses predicted that LK11 encodes genes for phosphate solubilization and nitrate/nitrite ammonification, which are beneficial for promoting plant growth. Genes for production of catalases, superoxide dismutase, and peroxidases that confer resistance to oxidative stress in plants were also identified in LK11. Moreover, genes for trehalose and glycine betaine biosynthesis were also found in LK11 genome. Similarly, Sphingomonas spp. analysis revealed an open pan-genome and a total of 8507 genes were identified in the Sphingomonas spp. pan-genome and about 1356 orthologous genes were found to comprise the core genome. However, the number of genomes analyzed was not enough to describe complete gene sets. Our findings indicated that the genetic makeup of Sphingomonas sp. LK11 can be utilized as an eco-friendly bioresource for cleaning contaminated sites and promoting growth of plants confronted with environmental perturbations.
\end{abstract}

Keywords Sphingomonas sp. LK11 $\cdot$ Endophyte $\cdot$ Plant growth promotion $\cdot$ Genome $\cdot$ SMRT sequencing

\section{Introduction}

Electronic supplementary material The online version of this article (https://doi.org/10.1007/s13205-018-1403-z) contains supplementary material, which is available to authorized users.

Abdul Latif Khan

latifepm78@yahoo.co.uk

$\triangle$ Ahmed Al-Harrasi

aharrasi@unizwa.edu.om

$\triangle$ In-Jung Lee

ijlee@knu.ac.kr

1 Natural and Medical Sciences Research Center, University of Nizwa, 616 Nizwa, Oman

2 School of Applied Biosciences, Kyungpook National University, Daegu 41566, Republic of Korea
Endophytic microorganisms, specifically bacteria or fungi, are known to inhabit plant tissues without causing disease symptoms in the host plant (Hallmann et al. 1997; Reissinger et al. 2001; Wilson 1995). Endophytic microbial communities have vital roles in the development and growth of various host plants under favorable and various stress conditions, such as heat, salinity, heavy metal contamination, and drought (Yaish et al. 2015). Among endophytes, bacteria have a knack for inhabiting internal plant tissues and imparting beneficial effects for host growth. Such traits have been shown to improve growth and developmental processes (Glick 1995; Ryan et al. 2008) of the host through the ability of endophytes to perform a range of functions, including assisting both primary and secondary nutrient uptake via atmospheric nitrogen fixation (Gothwal et al. 2008), synthesizing iron siderophores (Wang et al. 1993), and solubilizing minerals such as phosphate, potassium, and 
zinc (Basak and Biswas 2009; Iqbal et al. 2010; Kang et al. 2009). Facilitation of plant growth promotion by endophytic bacteria occurs through several mechanisms; these include mineralization of inorganic substances from the soil into host roots and production of enzymes, phytohormones, and defense-related constituents within the host environment (Khan et al. 2016a; Santoyo et al. 2016). In addition, these endophytic microbes can support the plant by providing nitrogen sources (by fixing atmospheric nitrogen into ammonia) and other nutrients, such as sulfur, iron, and phosphate. Furthermore, these microbes can protect their host plants from pathogenic attacks by regulating host plant physiology and phytohormones (Bach et al. 2016).

The endophytic bacterium Sphingomonas sp. LK11 was first isolated from the leaves of the arid medicinal plant Tephrosia apollinea and was subsequently found to actively increase growth and stress tolerance in tomato plants during salinity and cadmium stress (Halo et al. 2015; Khan et al. 2014). It has also been suggested that LK11 can produce phytohormones such as gibberellins (GAs) and auxins (Khan et al. 2014). Members of the genus Sphingomonas are yellow-pigmented, rod-shaped, nonsporulating, Gram-negative, chemoheterotrophic, and aerobic bacteria that belong to class Alphaproteobacteria within the phylum Proteobacteria (Busse et al. 2003). Sphingomonas species have been isolated from several different environments; novel strains have recently been isolated from abandoned heavy metal sites (Feng et al. 2014), forest soil (Kim et al. 2014), indoor air of pharmaceutical environments (Park et al. 2015), purplish paddy soil (Huang et al. 2014), glaciers (Miteva et al. 2004), volcano-associated lakes (Farias et al. 2011), space shuttles (Pan et al. 2016b), permafrost (Piao et al. 2016), and the sediment of a eutrophic reservoir (Huy et al. 2014). However, there are few reports describing Sphingomonas species as endophytes.

Sphingomonas species have been mostly described regarding their roles in remediating or degrading various kinds of organic and inorganic pollutants from different contamination sources. Similarly, the LK11 strain can reduce $\mathrm{Cd}^{2+}$ uptake, accumulate intracellular $\mathrm{Zn}^{2+}$, and increase metallothionein expression (which excludes heavy metals and prevents their binding by related proteins) in their host plants (Khan et al. 2014). This endophyte has the potential to thrive in high salinity (contaminated with sodium chloride) without utilizing its cellular mechanisms for producing antioxidants and related enzymes, such as peroxidases (PODs), polyphenol oxidases (PPOs), and catalases (CATs) (Halo et al. 2015). Furthermore, LK11 was recently reported to improve plant growth in both wild type and Got-3 mutant tomato plants when exogenously introduced to the plants via jasmonic acid (JA) treatment (Khan et al. 2017). The combined effects of LK11 and JA treatment caused plants to respond positively to salinity stressors by dramatically regulating glutathione content in Got-3 mutant and wild type tomato plants (Khan et al. 2017). Recent studies have also demonstrated the role of Sphingomonas spp. in the degradation of organic chemical compounds, such as bisphenol (Fujiwara et al. 2016), phenol (Gong et al. 2016), triclocarban (Mulla et al. 2016), phenanthrene (Liu et al. 2016), chlorogenic acid (Ma et al. 2016), nonylphenol polyethoxylates (Bai et al. 2016), astaxanthin (Ma et al. 2016), dioxin (Miller et al. 2010), $\gamma$-hexachlorocyclohexane (Tabata et al. 2013), nicotine (Zhu et al. 2016), plasticizers (Kera et al. 2016), and hexachlorocyclohexane isomers (Kumari et al. 2002) among others. In addition to these degradation abilities, the Sphingomonas genus can also produce bioactive metabolites, such as indole acetic acid, gibberellins, sphingan (Li et al. 2016), and gellan gum (Gai et al. 2011b).

Previous studies have suggested the potential of LK11 as a plant growth-promoting bacterium; however, this strain has not been fully investigated for these characteristics. Therefore, the current study aimed to elucidate the whole LK11 genome and its plant growth-promoting activity. Sequencing the complete genome of LK11 will aid in resolving the complex biological mechanisms of this microorganism that promote plant growth and induce hardiness against salinity and heavy metal stress. These genomic analyses will provide a foundation towards fully understanding the characteristics of this microorganism and its potential for broader application against environmental stressors. Furthermore, comparisons with other completely sequenced Sphingomonas genomes will help delineating the unique and shared traits among different Sphingomonas species, offering insights into the evolutionary changes that have occurred within this genus.

\section{Materials and methods}

\section{Detection of gibberellins (GAs) in cell-free cultures}

Sphingomonas sp. LK11 was cultured in NB media and incubated for 7 days at $30{ }^{\circ} \mathrm{C}$ and $200 \mathrm{rpm}$. Quantification of GA in bacterial cultures was carried out according to the protocol described by Kang et al. (2016) and Waqas et al. (2012). Bacterial culture filtrates supplemented with $\left[{ }^{2} \mathrm{H}_{2}\right]$ GA standards were processed for detection, identification, and quantification of GA using gas chromatography and mass spectroscopy.

\section{Sphingomonas sp. LK11-plant interaction}

Healthy soybean seeds were obtained from the Soybean Genetic Resource Center (Kyungpook National University, Daegu, South Korea) with a 95\% germination rate. Surface sterilization and germination experiments were carried out according to Asaf et al. (2017b). Sterilized germination trays 
and pots were filled with horticulture soil that had been autoclaved $\left(121^{\circ} \mathrm{C}\right.$ and 15 psi for $\left.15 \mathrm{~min}\right)$ three times and had the nutrient composition of peat moss (Asaf et al. 2016). After germination, randomly selected uniform plant seedlings were planted in one round plastic pot $(10 \times 9 \mathrm{~cm})$ and grown for 20 days using one of two treatments, (1) control plants without LK11 or (2) plants inoculated with LK11. Distilled water was applied to plants as needed and with care to prevent leaching. LK11 cells dissolved in $35-\mathrm{mL}$ sterilized double-distilled water were applied three times to treatment (1) plants to ensure efficient transformation and then twice consecutively at 1-week intervals. Endophyte cells were collected as described above. The harvested cells were then washed with $0.8 \% \mathrm{NaCl}$ solution and dissolved in autoclaved double-distilled water adjusted to an optical density (OD) of 0.5. Different plant physiological parameters like shoot length, root length, and fresh and dry weight were analyzed. Furthermore, plants were transferred to liquid nitrogen and freeze-dried for 1 week using a freeze dryer (VirTis, Gardiner, NY, USA) for GA analysis.

\section{Quantification of endogenous GAs in soybeans treated with LK11}

Quantification of GAs in the freeze-dried samples of soybean plants was carried out according to the protocol established by Lee et al. (1998) using gas chromatography with a mass spectrometer (6890N Network GC system and 5973 Network Mass Selective Detector; Agilent Technologies). The results were calculated in ng/gof freeze-dried weight of plant samples.

\section{DNA extraction, genome sequencing, and genome assembly}

Sphingomonas sp. LK11 was previously isolated and identified by Khan et al. (2014). For complete genome sequencing, genomic DNA of LK11 was extracted from an overnight cell suspension culture using the Qiagen ${ }^{\mathrm{TM}}$ QIAamp DNA Mini Kit (Qiagen, Hilden, Germany). Complete genome sequencing was performed using the Single Molecule Real Time (SMRT) sequencing technology of Pacific Biosciences (PacBio, Menlo Park, CA, USA) as described previously (Chan et al. 2014). Briefly, a PacBio large insert library $(15-20 \mathrm{~kb})$ was constructed from high molecular DNA $(120.0 \mathrm{ng} / \mu \mathrm{L})$ and sequenced on four V2 SMRT cells using P4-C2 chemistry with a running movie for $4 \mathrm{~h}$ at the Duke Center for Genome and Computational Biology, Duke University (Durham, NC, USA). PacBio produces data in HDF5 format $(* . h 5)$ and the corresponding input file of SMRT Analysis software is a bas.h5 file or an associated bax.h5 file. Assemblies were evaluated to ensure data quality using QUAST 2.3 (Gurevich et al. 2013). A total of 84,384 reads, with a mean read length of $11,888 \mathrm{bp}$, was generated. The reads were de novo assembled into a circular chromosome and two circular plasmids, with an average genomic coverage of 150.26 reads (Table S1), using the Hierarchical Genome Assembly Process (HGAP) workflow in SMRT Portal (version 2.1.1).

\section{Genome annotation}

Complete genome annotation was performed using the NCBI Prokaryotic Genome Annotation Pipeline (Angiuoli et al. 2008). This annotation was used to predict coding genes through an $a b$ initio gene prediction algorithm with homology-based methods. The annotation process helped elucidate functional genomic units, such as structural RNAs (5S, 16S, and 23S), tRNAs, and small noncoding RNAs. Additional gene prediction analysis and functional annotation were performed by Rapid Annotation using Subsystem Technology (RAST) version 3.0 (Aziz et al. 2008a, b; Brettin et al. 2015; Overbeek et al. 2014) and the Integrated Microbial Genomes platform (IMG) (Markowitz et al. 2012). The assembled and annotated sequences of LK11 (one chromosome and two plasmids) were deposited in GenBank with accession numbers CP013916-CP013918. This information was submitted to the Genomes Online Database (Gs0118031) (Reddy et al. 2015).

\section{Comparative genome analysis}

To understand the genomic features of Sphingomonas sp. LK11 (CP013916), comparative assessments were made with the recently reported genome sequences of Sphingomonas sp. MM1 [CP004036; (Tabata et al. 2013)], Sphingomonas sp. NIC1 [CP015521; (Zhu et al. 2016)], Sphingomonas taxi [CP009571; (Eevers et al. 2015)], and Sphingomonas hengshuiensis [CP010836; (Wei et al. 2015)] —all of which were obtained from NCBI. Gene prediction and functional annotation of these Sphingomonas spp. were performed using the RAST subsystem (Aziz et al. 2008b; Brettin et al. 2015; Overbeek et al. 2014). For comparison purposes, we created a circular genomic map of each genome using Interactive Microbial Genome Visualization with GView (Petkau et al. 2010) and Ring Image Generator (BRIG, version 0.95) (Alikhan et al. 2011). Each circular genomic map was generated with BLAST+, with standard parameters (70\% lower and $90 \%$ upper cutoff for identity and $E$ value of 10), using the LK11 genome as the "alignment reference genome." Pan-genome and core genome analyses of LK11 against related species were carried out using EDGAR version 2.0 (Blom et al. 2009) and PGAP version 1.12 (Zhao et al. 2012). 


\section{Results and discussion}

\section{Plant growth-promoting traits of Sphingomonas sp. LK11}

The results showed that LK11 produces different quantities of GAs in its pure culture; these included $\mathrm{GA}_{1}, \mathrm{GA}_{3}, \mathrm{GA}_{8}$, $\mathrm{GA}_{9}, \mathrm{GA}_{24}, \mathrm{GA}_{53}, \mathrm{GA}_{12}, \mathrm{GA}_{20}, \mathrm{GA}_{19}, \mathrm{GA}_{34}, \mathrm{GA}_{4}$, and $\mathrm{GA}_{7}$ (Fig. 1a). Among these, physiologically active GA3 and GA4 were produced in significantly high quantities while inactive $\mathrm{GA}_{53}$ and $\mathrm{GA}_{19}$ were abundant in the pure culture of Sphingomonas sp. LK11. Other GAs were present in very small quantities (Fig. 1a). This is in agreement with a previous report by Khan et al. (2014) on the production of GA in pure culture; however, we found increased abundance of other GAs, such as $\mathrm{GA}_{1}, \mathrm{GA}_{3}, \mathrm{GA}_{8}, \mathrm{GA}_{24}$, $\mathrm{GA}_{53}, \mathrm{GA}_{12}, \mathrm{GA}_{20}, \mathrm{GA}_{19}$, and $\mathrm{GA}_{34}$, which is reported for the first time in the LK11 strain. Previous studies have shown that some bacterial strains also produce ${ }_{\mathrm{GA}} \mathrm{s}$, e.g., Rhizobium phaseoli (Atzorn et al. 1988), Acetobacter diazotrophicus (Bastián et al. 1998), B. licheniformis
(Gutiérrez-Mañero et al. 2001), B. cepacia SE4 (Kang et al. 2014), Leifsonia xyli SE134 (Kang et al. 2017), and Bacillus amyloliquefaciens RWL-1 (Shahzad et al. 2017).

Since Sphingomonas sp. LK11 produces GAs, we examined the plant growth-promoting potential by inoculating soybean plants with pure LK11 culture. The results showed that Sphingomonas sp. LK11 significantly increased shoot, root, and plant biomass compared with control plants (Fig. 1b). This was further validated by changes in endogenous GA content of soybean plants. $\mathrm{GA}_{3}(88.2 \%), \mathrm{GA}_{7}$ (8.2\%), and $\mathrm{GA}_{4}(23.8 \%)$ were significantly higher in LK11inoculated soybean plants than in control plants (Fig. 1d). Nagel and Peters (2017) suggested that bacterial strains possess active GA biosynthesis pathways as well as $\mathrm{GA}_{4}$ and $\mathrm{GA}_{9}$. Furthermore, such plant growth-promoting effects have been previously suggested due to the potential of microbes in producing phytohormone-like compounds (Khan et al. 2015). It has been reported that Sphingomonas sp. LK11 improves tomato plant growth (Khan et al. 2014), which is consistent with studies by Xu et al. (1998), Cerny-Koenig et al. (2005), Kang et al. (2014), and Shahzad et al. (2017), which showed that GA-producing bacteria are beneficial for

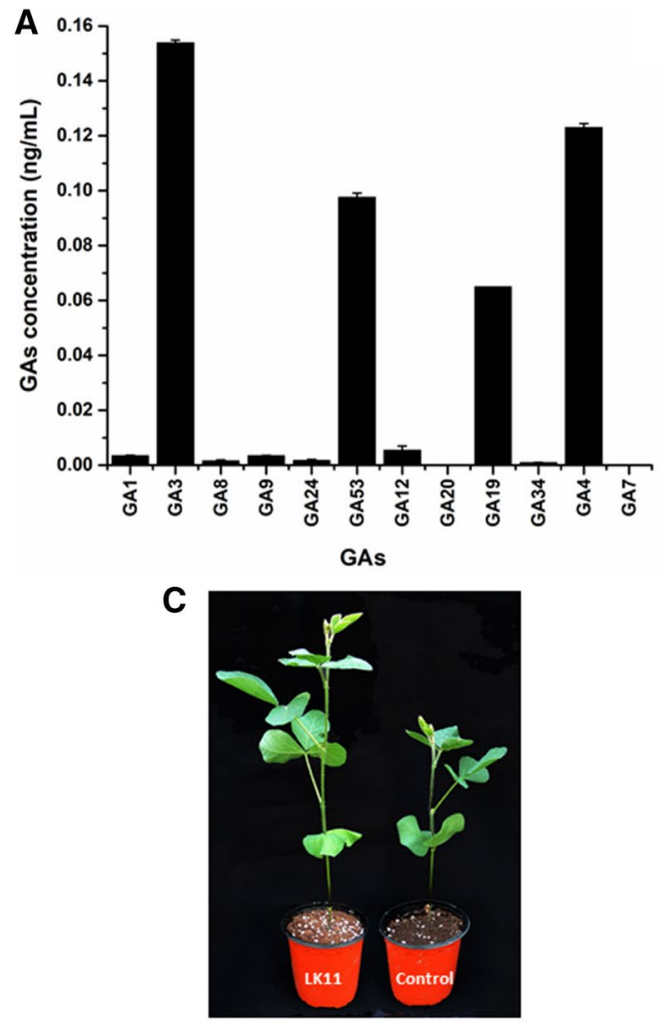

Fig. 1 Gibberellin (GA) production by Sphingomonas sp. LK11 (a). Bacterial culture was centrifuged and $100 \mathrm{~mL}$ of the culture filtrate was analyzed for the presence of GAs using a GA extraction protocol. The bar indicates standard deviation between replicates. Effect of Sphingomonas sp. LK11 culture on $(\mathbf{b}, \mathbf{c})$ different growth attributes

B

\begin{tabular}{|l|l|l|l|l|}
\hline & Shoot Length & Root Length & Fresh weight & Dry weight \\
\hline Control & $7.45 \pm 0.28 \mathrm{~b}$ & $21.64 \pm 0.007 \mathrm{~b}$ & $66.48 \pm 0.007 \mathrm{~b}$ & $9.48 \pm 0.23 \mathrm{a}$ \\
\hline LK11 & $11.84 \pm 0.678 \mathrm{a}$ & $33.75 \pm 0.707 \mathrm{a}$ & $91.82 \pm 0.307 \mathrm{a}$ & $9.55 \pm 0.14 \mathrm{a}$ \\
\hline
\end{tabular}

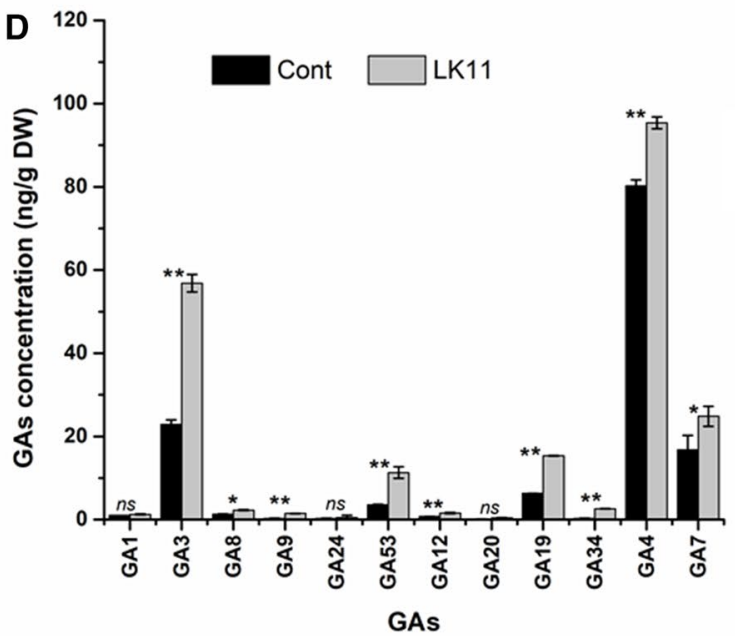

and (d) endogenous GA of soybean plants. Same letters indicate nonsignificant difference within treatment, while $(*)$ and $(* *)$ indicate significant and very significant differences, respectively. (ns) represents non-significant difference among different types of GAs 
improving crop growth. In addition, utilization of bacteria isolated from arid land ecosystems is more compatible with improving plant growth during harsh environmental conditions (Asaf et al. 2017b). Due to the ecological importance of such strains, we performed whole-genome sequencing of Sphingomonas sp. LK11.

\section{Sphingomonas sp. LK11 genome in comparison with related species}

The complete genome of Sphingomonas sp. LK11 was found to consist of a $3781,071 \mathrm{bp}$ circular chromosome with a $\mathrm{G}+\mathrm{C}$ content of $66.2 \%$ and two circular plasmids of 122,975 bp and 34,160 bp with $\mathrm{G}+\mathrm{C}$ contents of 63 and $65 \%$, respectively (Fig. 2; Table 1). When combined, the chromosome and plasmids contained 3739 annotated genes, including 59 tRNAs, 4 complete rRNA, and 3656 protein-coding sequences (CDSs; Table 1). Among these CDSs, 2388 (63.87\%) genes were classified into clusters of orthologous group (COG) families comprised of 23 categories (Table S2). The genome size of LK11 falls within the
Table 1 Gene prediction and annotation summary

\begin{tabular}{ll}
\hline Annotation statistics & \\
\hline Genome size (bp) & $3,938,206$ \\
GC & 66.05 \\
Total number of genes & 3739 \\
Number of CDSs & 3656 \\
Pseudogenes & 114 \\
rRNA genes & 12 \\
tRNA genes & 59 \\
Protein-coding genes with function prediction & 2785 \\
Protein-coding genes without function prediction & 871 \\
Protein-coding genes encoding enzymes & 1001 \\
Protein coding genes connected to KEGG pathways & 1076 \\
Protein coding genes connected to KEGG Orthology & 1852 \\
(KO) & \\
Protein coding genes connected to MetaCyc pathways & 876 \\
Protein coding genes with COGs & 2388 \\
\hline
\end{tabular}

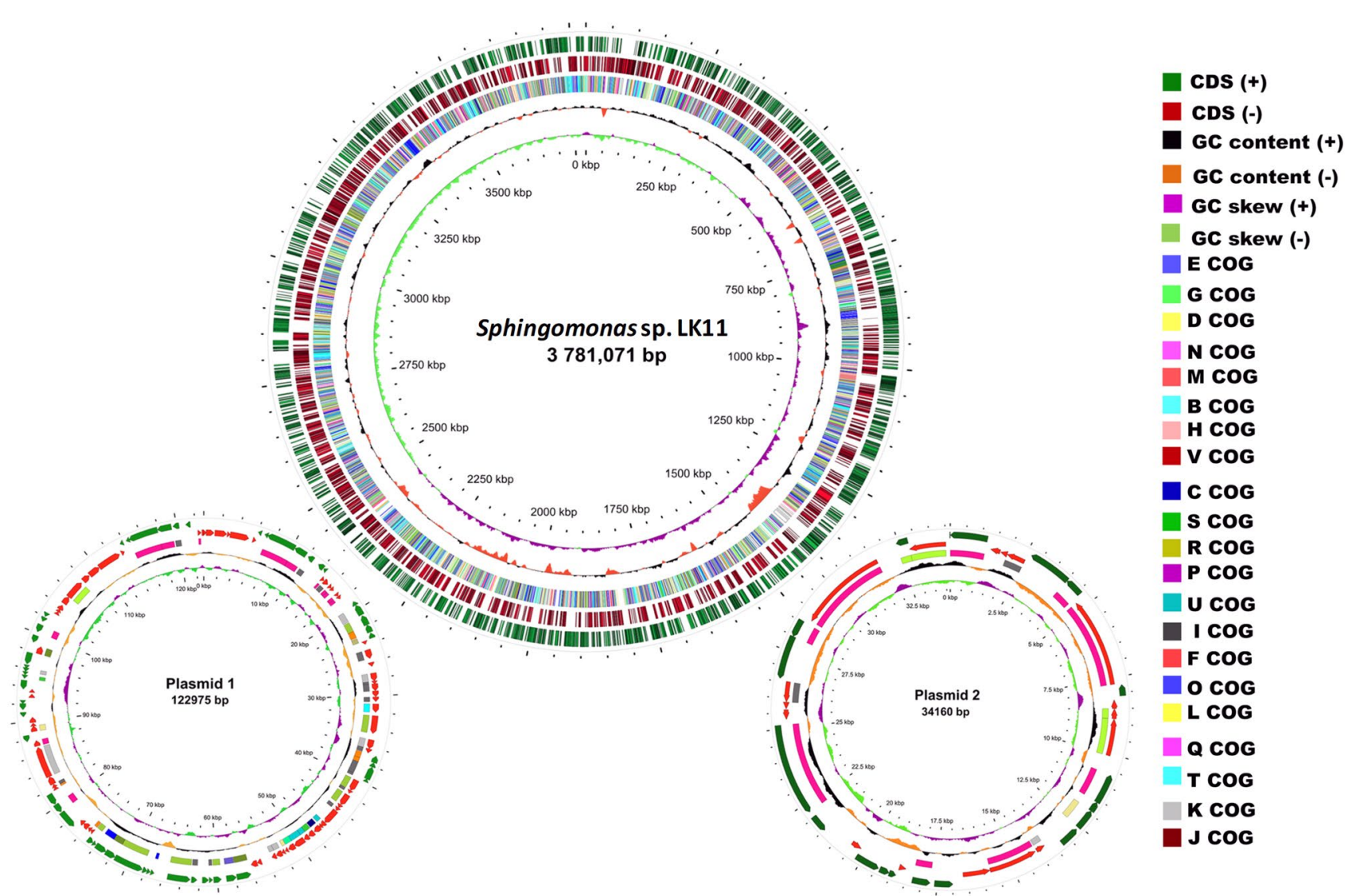

Fig. 2 Circular representation of the Sphingomonas sp. LK11 genome. From outer to inner circles, the two outer circles show the predicted protein-coding sequences on the plus (green) and minus (red) strand. The third circle shows the distribution of genes related to Clusters of Orthologous Groups (COGs) categories, while the fourth and fifth circles show $\mathrm{G}+\mathrm{C}$ content and $\mathrm{G}+\mathrm{C}$ skew, respectively 
expected range (based on other genomic studies) and a varying number of plasmid has been observed in other strains (Gai et al. 2011a; Kera et al. 2016; Li et al. 2016; Miller et al. 2010; Pan et al. 2016a).

Based on the diverse functional roles of species belonging to genus Sphingomonas, 2785 (74.49\%) LK11 genes were assigned specific biological roles; this was also based on results from BLASTn homology searches. The remaining CDSs were categorized as proteins with unknown functions. Proteins, rRNAs, and tRNAs are encoded by $88.59 \%, 0.52 \%$, and $0.121 \%$ of the complete genome, respectively, while the remaining $10.76 \%$ of the genome is made up of noncoding regions.

\section{Plant growth-promoting potential of Sphingomonas sp. LK11}

From the genomic sequence of Sphingomonas sp. LK11, we analyzed genes that are categorized by their ability to enhance nutrient availability, catabolize aromatic compounds, and resist oxidative and other forms of abiotic stress (Table 2). Very few Sphingomonas species are reported to stimulate plant growth through the production of phytohormones or enzymes (Dodd et al. 2010). On the other hand, LK11 was shown to enhance plant growth through the production of GAs (Fig. 1b, c) and IAA (Khan et al. 2014). However, a complete IAA biosynthetic pathway was not found in LK11 during genome analysis, although some genes responsible for IAA production, such as the tryptophan biosynthesis gene cluster $(\operatorname{trp} A, \operatorname{trp} B$, and $\operatorname{trp} D)$ and indole pyruvate ferredoxin oxidoreductase (IOR; locus AV944_07715 and locus AV944_07710, respectively) were present. It has been well-established that the presence of tryptophan-related genes in bacterial genomes is linked to IAA biosynthesis and related biological functions (Gupta et al. 2014; Tadra-Sfeir et al. 2011).

The LK11 genome also encodes cystathionine $\gamma$-lyase (CSE; locus AV944_16960), 3-mercaptopyruvate sulfurtransferase (3MST; locus AV944_12370), cystathionine $\beta$-synthase (CBS), and cysteine aminotransferase (CAT; locus AV944_01390), which are known for hydrogen sulfide $\left(\mathrm{H}_{2} \mathrm{~S}\right)$ production. $\mathrm{H}_{2} \mathrm{~S}$ production by plant growthpromoting rhizobacteria (PGPR) has been reported to enhance plant growth, seed germination, and root colonization (Dooley et al. 2013). The presence of an ATP-binding cassette $(\mathrm{ABC})$ transporter that includes periplasmic binding proteins encoded by $c y s P, \operatorname{cys} T$, cys $W$, and $c y s A$ in the LK11 genome revealed that these genes may be involved in the transportation of thiosulfate or inorganic sulfate to cells as reported earlier in Pseudomonas sp. UW4 (Duan et al. 2013). The presence of these genes in bacterial strains has been linked to oxidation of sulfur and sulfur-conjugated metabolites (Kwak et al. 2014). Moreover, sulfur oxidation influences soil $\mathrm{pH}$ and sequentially improves solubility of micronutrients, such as $\mathrm{N}, \mathrm{P}, \mathrm{K}, \mathrm{Mg}$, and $\mathrm{Zn}$ (Vidyalakshmi et al. 2009). Therefore, the association of such endophytic microbes can provide improved mineral acquisition and allocation to the host plants.

We also identified glucose-1-dehydrogenase ( $g c d$; locus AV944_13915) in the LK11 genome, suggesting that LK11 can solubilize inorganic mineral phosphates, making it a potential inoculant candidate for increasing phosphorous uptake in plants. Some bacteria were reported to solubilize insoluble mineral phosphates by producing organic acids (mainly gluconic acid) and acid phosphatases (Achal et al. 2007), where the production of gluconic acid is assisted by $g c d$ (de Werra et al. 2009). Inorganic phosphates are important for plant growth and thus microbes can assist plants by mobilizing complex phosphates into more solubilized forms (Gupta et al. 2012). Several bacteria such as Gluconobacter oxydans, Pseudomonas fluorescens, Azospirillum spp., and Mesorhizobium mediterraneum have shown phosphatesolubilizing abilities (de Werra et al. 2009; Peix et al. 2001; Rodriguez et al. 2004).

In addition to $g c d$, the phosphate-specific transport ( $p s t)$ system is used for free inorganic phosphate transport in
Table 2 Genes attributed to plant growth promoting traits in the LK11 genome

\begin{tabular}{|c|c|}
\hline Plant growth promotion traits & Genes with potential for PGP traits \\
\hline Phosphate metabolism & pstC, pstA, phoU, phoQ, nad(P), phoR (sphS), phoB, pstB, oprO, pstS \\
\hline IAA production & $\begin{array}{l}\text { Tryptophan synthase } \alpha \text { chain }(\operatorname{trp} A) \text {, Anthranilate phosphoribosyltrans- } \\
\text { ferase }(\operatorname{trp} D) \text {, Tryptophan synthase } \beta \text { chain }(\operatorname{trp} B) \text {, Phosphoribosylan- } \\
\text { thranilate isomerase }(P A I)\end{array}$ \\
\hline Trehalose metabolism & trehalose synthase gene homolog \\
\hline Chitinase & Chitinase gene homolog \\
\hline H2S Production & cys $P$, cys $W$, cys $T$, cys $A$ \\
\hline Heat shock proteins & dnaK, hrcA, dnaJ, rpoH, lepA, rdqB, smpB, grpE \\
\hline Cold shock proteins & $\operatorname{csp} A, \operatorname{csp} B$ \\
\hline Superoxide dismutase & Superoxide dismutase gene homologs \\
\hline Sulfur assimilation & cys $T$, cys $W$, cys $P$, cysA, cys $Q$, cys $X$, sat 1, sat 2 \\
\hline
\end{tabular}


Bacillus subtilis and Escherichia coli. The pst operon of E. coli and B. subtilis is composed of pstS, pstC, pstA, and $p s t B$ as well as a two-component signal transduction system consisting of $p h o P / p h o R$ for phosphate uptake (Xie et al. 2016). In the present study, genomic analyses of LK11 revealed that it also carries the $p s t$ operon (pstA, pstB, pstC, and $p s t S$ genes; locus AV944_10605, locus AV944_10610, locus AV944_10600, and locus AV944_10615, respectively), as well as phoB (locus AV944_10590), phoP (locus AV944_05370), and phoR (locus AV944_10620) genes for phosphate transport.

\section{Sphingomonas sp. LK11 in osmotic stress}

Plants are often exposed to abiotic stresses such as heat, drought, metal contamination, and high salinity. In such circumstances, inoculating plants with symbiotic, stress-regulating microbes can provide them with additional means of combating stress conditions (Khan et al. 2015; Yang et al. 2009). Abiotic stresses can create osmotic deficiencies in plant cells, while microorganisms in the phyllosphere can produce extracellular polysaccharides to protect not only themselves but their plant hosts from adverse effects (Beattie and Lindow 1999). Recently, Sphingomonas sp. LK11 was reported to significantly increase plant height, biomass, and glutathione, amino acid, and primary sugar levels compared with control under varying drought stresses (Asaf et al. 2017a). These findings were further validated by the presence of trehalose biosynthesis pathways (otsA/otsB and treYltreZ) in the genome of LK11. Trehalose can act as an osmoprotectant and the otsA/otsB pathway is considered the most widely occurring biochemical pathway in many organisms that are under environmental stressors, such as high salinity, drought, low temperature, and osmotic stress (Duan et al. 2013; Garg et al. 2002). Moreover, trehalose production protects microbes from oxidative stress, including exposure to hydrogen peroxide (Pilonieta et al. 2012). This is supported by a recent study where exogenous trehalose and Sphingomonas sp. LK11 inoculation of soybean plants significantly mitigated polyethylene glycol-induced drought stress through activating endogenous primary sugars (Asaf et al. 2017a). The presence of these trehalose pathways in the LK11 genome suggests that this strain can aromatic hydrocarbons. It has also been demonstrated that trehalose accumulation may act as a biosurfactant that enhances biodegradation of hexachlorocyclohexane, which was previously reported for Sphingomonas sp. NM05 (Garg et al. 2002; Manickam et al. 2012).

In addition, the LK11 genome was found to contain a number of salt tolerance genes that can synthesize the osmolyte glycine betaine from choline by encoding the bet $T$ choline transporter (Lamark et al. 1996), the betA choline dehydrogenase, and the betB betaine aldehyde dehydrogenase. The presence of these genes further validates our recent findings related to the role of LK11 in resisting salinity stress and promoting plant growth (Halo et al. 2015). LK11 also contains $\mathrm{Na}^{+} / \mathrm{H}^{+}$antiporters (nha) that have also been shown to alleviate salinity stress (Epstein 2003).

\section{PGPR fitness against oxidative stress in Sphingomonas sp. LK11}

Plants use various strategies to protect themselves from numerous viral, bacterial, and other threats. These strategies include the formation of reactive oxygen species (ROS; superoxide, hydroxyl radical, and hydrogen peroxide), phytoalexins, and nitric oxide (HammondKosack and Jones 1996; Zeidler et al. 2004). Aerobic organisms utilize various enzymes and antioxidants to manage oxidative stress resulting from the detrimental byproducts of aerobic respiration (Cabiscol et al. 2000; Lushchak 2001).

The LK11 genome encodes genes to protect itself during the activation of plant defense mechanisms; such genes encode glutathione S-transferase (locus AV944_12110, locus AV944_13280, and locus AV944_05350), glutathione peroxidases (locus AV944_12175), superoxide dismutases (SODs; locus AV944_13570 and locus AV944_06030) and glutathione-disulfide reductase (locus AV944_15970). Furthermore, the LK11 genome contains five genes encoding different catalases (locus AV944_17575) and eight genes encoding peroxidases. Genes encoding three peroxiredoxins and two glutaredoxins were also identified. As endophytic bacteria can mitigate oxidative stress, they could strengthen plant defenses against abiotic stress-induced ROS generation (Khan et al. 2017). This is also in agreement with a previous study where LK11 counteracted sodium chloride-induced ROS generation by increasing the activity of catalase, superoxide dismutase, and reduced glutathione (Halo et al. 2015).

\section{Cold shock and heat shock proteins in Sphingomonas sp. LK11}

Under different environmental conditions, some bacteria can regulate cold shock and heat shock protein levels. The cold shock protein family comprises small, structurally related, and highly conserved nucleic acid-binding proteins that appear to contribute significantly to the management of numerous microbial physiological processes (Ermolenko and Makhatadze 2002). These proteins are extensively distributed among prokaryotes and are frequently encoded through differentially regulated, multiple gene families (Graumann and Marahiel 1998; Phadtare 2004). The LK11 genome contains the cold shock protein genes $\operatorname{csp} A$ and $\operatorname{csp} B$ (locus AV944_00095 and locus AV944_14525, respectively) and the heat shock protein genes dnaJ and dnaK (locus

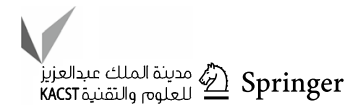


AV944_15200 and locus AV944_15205, respectively), grpE (locus AV944_15230), hrcA (locus AV944_15235), and rpoH (locus AV944_13700). These genes have been linked to the modulation of cold and heat adaptive functions. The presence of these genes further confirms our previous results where chaperone and L10 family of ribosomal proteins were significantly upregulated in response to cadmium-induced toxicity (Khan et al. 2014).

\section{Heavy metal resistance and improving phytoremediation strategies}

Many bacterial species possess mechanisms that make them resistant or tolerant to heavy metals (Diels et al. 1995; Ji and Silver 1995; Kunito et al. 1996). Our analysis of the LK11 genome revealed the presence of a $c z c$ operon in the chromosome and plasmids. The $c z c$ operon was found comprised of three structural genes, $c z c A, c z c B$, and $c z c C$, as well as two regulatory genes, $c z c D$ and $c z c R$ (Table 3 ). This operon was previously found to confer resistance to three heavy metals, namely cobalt, zinc, and cadmium (Kunito et al. 1996; Nies 1995; Silver and Phung 1996). Various models of the $c z c$ efflux system have been proposed for different bacteria (Nies 1992). The most commonly occurring model was found in the LK11 genome where the efflux system exists as a dimmer (Fig. 3); this model was suggested by Diels et al. (1995) and was adopted by Silver (1996). Furthermore, the arsenic resistance genes $\operatorname{ars} B$ and $\operatorname{ars} C$ were found on the LK11 chromosome. Previous studies have shown that $\operatorname{ars} B$ and $\operatorname{ars} C$ encode arsenate reductase and aid in arsenite efflux transport (Duan et al. 2013).

In addition, the LK11 genome also carries genes involved in copper resistance on its chromosome and plasmids (Table 3). Most of the bacterial genes that confer copper
Table 3 Genes potentially involved in metal resistance in the LK11 genome

Fig. 3 Proposed model for the $c z c$ efflux system in LK11 as suggested by Ludo Diels and adopted by Simon Silver (1996). It has been reported that $\mathrm{CzcC}$ is a cell wall "outer" membrane protein, CzcA is an "inner" plasma membrane transport protein, while $\mathrm{CzcB}$ is a membrane fusion protein that extends through both membranes

\begin{tabular}{|c|c|c|}
\hline Gene & Locus & Product \\
\hline$c z c A$ & AV944_17755 & Cobalt/zinc/cadmium resistance protein CzcA \\
\hline$c z s B / c u s B$ & AV944_17760 & $\begin{array}{l}\text { Cobalt/zinc/cadmium efflux RND transporter, membrane } \\
\text { fusion protein, CzcB family }\end{array}$ \\
\hline$c z c C$ & AV944_17765 & Heavy metal RND efflux outer membrane protein, $\mathrm{CzcC}$ family \\
\hline$c z c D$ & AV944_17715 & Cobalt/zinc/cadmium resistance protein $\mathrm{CzcD}$ \\
\hline$c z c R$ & AV944_17775 & Cobalt/zinc/cadmium resistance protein $\mathrm{CzcD}$ \\
\hline$h m r R$ & AV944_17780 & Transcriptional regulator, MerR family \\
\hline сиеA & AV944_17735 & Copper-translocating P-type ATPase (EC 3.6.3.4) \\
\hline catalase hpII & AV944_17575 & Catalase related to oxidative stress \\
\hline сорA & AV944_17735 & Multi-copper oxidase \\
\hline $\operatorname{cop} B$ & AV944_00295 & Copper resistance protein \\
\hline $\operatorname{cop} C$ & AV944_14760 & Copper homeostasis \\
\hline $\operatorname{ars} B$ & AV944_04475 & Arsenic efflux membrane protein \\
\hline $\operatorname{ars} C$ & AV944_07460 & Arsenate reductase \\
\hline
\end{tabular}


resistance are carried on plasmids and are organized in operons (Dupont et al. 2011; Magnani and Solioz 2007; Wei et al. 2009). It has been shown that copper resistance is encoded by the $\operatorname{cop} A, \operatorname{cop} B, \operatorname{cop} C$, and $\operatorname{cop} D$ genes in various bacteria (Mellano and Cooksey 1988; Voloudakis et al. 2005). During genome analysis, we found that LK11 possess $\operatorname{cop} A$, a gene that encodes multi-copper oxidase; this gene is one of the main genetic elements involved in copper resistance in Gram-negative bacteria (Lejon et al. 2007; Nies 1999; Rensing and Grass 2003). Multi-copper oxidase is considered a marker gene for copper-resistant bacteria (Voloudakis et al. 2005). Moreover, plasmid 1 of LK11 contains the cueA gene (Table 3), which encodes a coppertransporting P-type ATPase for copper homeostasis. This gene is found in other bacteria especially in copper-resistance bacteria (Magnani and Solioz 2007). Previously, the plasmid pMOL28 of Cupriavidus metallidurans strain CH34 was found to confer resistance to nickel and cobalt toxicity (Liesegang et al. 1993; Tibazarwa et al. 2000) while plasmid pMOL30 conferred resistance against zinc, cadmium, cobalt (Nies and Silver 1989), and copper (Monchy et al. 2006). The presence of such genes in the Sphingomonas sp. LK11 plasmid coding for transport of metal ion supports its potential in microbe-assisted phytoremediation as previously reported (Khan et al. 2016b).

\section{Pan-genomic analysis of LK11}

The pan-genome defines the complete complement of genes existing in a clade. In the present study, the full genomic sequences of LK11 and four other Sphingomonas species were used to investigate the core and pan-genome of sphingomonas genus. The core and pan-genome sizes were plotted against the number of genomes analyzed in this study. When additional genomes were added, the number of analogous gene clusters comprising the core genome dropped slightly, while the number of unique gene clusters in the pan-genome steadily increased. Extrapolation of the curve showed that the core genome contains a minimum of 1356 genes $(95 \%$ confidence interval $=1209.4-1295.155)$ with the addition of Sphingomonas taxi, Sphingomonas hengshuiensis, Sphingomonas sp. MM1, and Sphingomonas sp. NIC1 genomes. The definitive number of shared genes in each genome deviates due to paralogs and duplicated genes (Fig. 4).

Furthermore, pan-genome analysis revealed that for every Sphingomonas species genome sequenced, an average of 1000 new genes were added to the pan-genome (Fig. 4). Likewise, the pan-genome curve showed that the representative species from genus Sphingomonas displayed an open pan-genome. The number of genomes examined were not enough to explain the complete gene sets and thus genomic sequencing of more Sphingomonas species is required to describe all genes of this genus. Furthermore, conserved genes are present across bacterial genomes within the same genus or species. A conserved fraction of these genes-specifically, those that are similar and found in all (or most) of the genomes within a given bacterial taxonomic group - is called the "core genome" of that group. The core genome can be identified on both the species and genus level (Leekitcharoenphon et al. 2012) and can be used to identify variable genes in a given genome (Adekambi et al. 2011). In general, conserved genes appear to evolve more slowly and can be used for establishing associations among various bacterial isolates (Urwin and Maiden 2003).

Additionally, the Venn diagram shows that 1356 genes are shared by all five Sphingomonas species analyzed. LK11 shares 53, 77, 133, and 87 genes exclusively with Sphingomonas sp. MM1, Sphingomonas sp. NIC1, Sphingomonas taxi, and Sphingomonas hengshuiensis, respectively (Fig. 5). The number of unique genes possessed
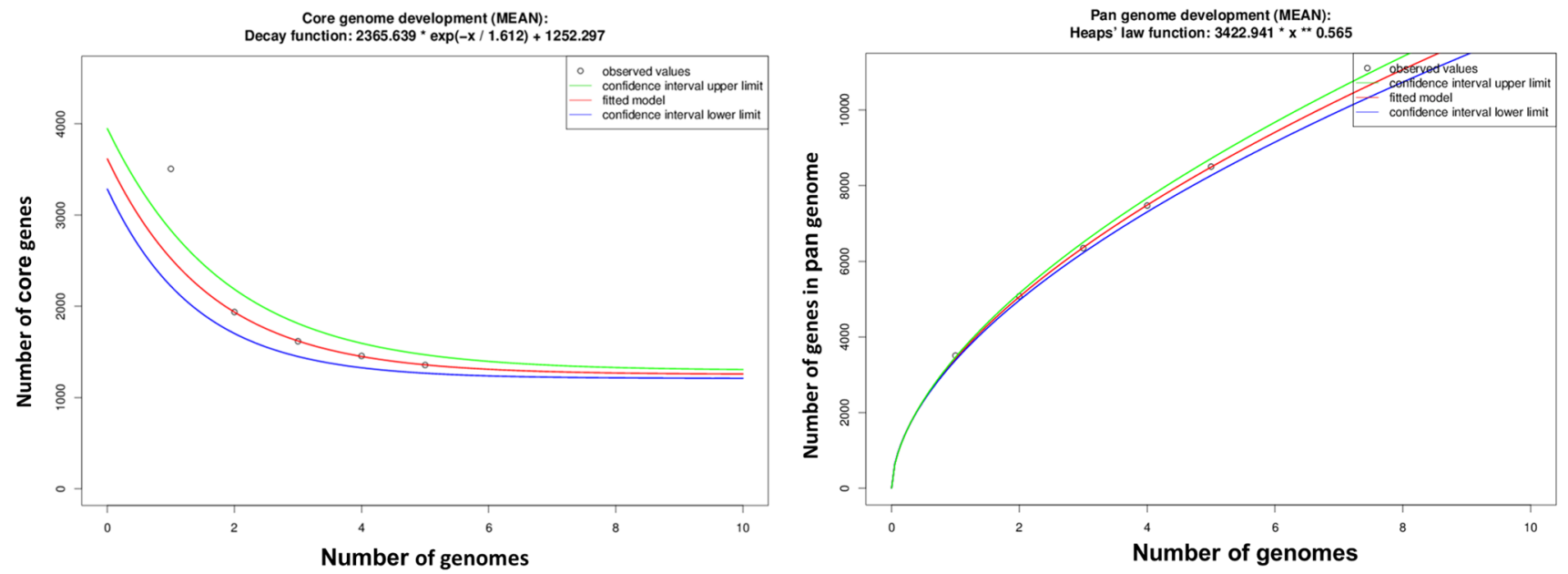

Fig. 4 The number of gene clusters in the core and pan-genomes is plotted against the number of Sphingomonas spp. genomes sequenced 


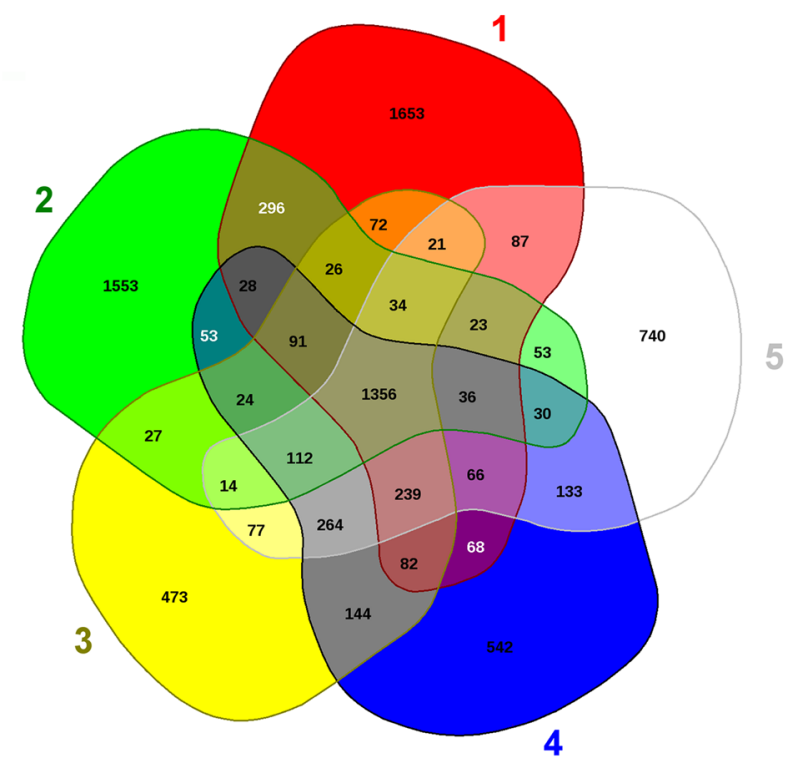

\section{1: Sphingomonas hengshuiensis $\quad$ 2: Sphingomonas sp. MM1 \\ 3: Sphingomonas sp. NIC1 4: Sphingomonas taxi}

5: Sphingomonas sp. LK11

Fig. 5 Venn diagram illustrating the orthologous gene complements of Sphingomonas sp. LK11 with Sphingomonas sp. MM1, Sphingomonas sp. NIC1, Sphingomonas taxi, and Sphingomonas hengshuiensis. Numbers in the outer circles represent the total number of unique genes identified in each genome while numbers in the center represent the number of orthologous sequences common to all five genomes

by LK11, Sphingomonas sp. MM1, Sphingomonas sp. NIC1, Sphingomonas taxi, and Sphingomonas hengshuiensis were 740,1553,473, 542, and 1653, respectively (Fig. 5). Finally, the unique genes possessed by LK11 mostly encode hypothetical proteins and their GC content ranges from 48.6 to $75.1 \%$ with an average of $65 \%$ (Table S3). These unique genes include glutaredoxinrelated (locus AV944_14990 and AV944_14990) and thioredoxin-related (locus AV944_10100) genes, which may be responsible for maintaining a cellular redox environment and may control oxidative stress responses in LK11 as previously reported (Zeller and Klug 2006). In addition, the genome of LK22 also includes the ars $R$ gene family, which is a transcriptional regulatory protein class known to counter stress generated by heavy metal toxicity. Furthermore, TonB-dependent transporter-related genes were also found in LK11. TonB-dependent transporters are bacterial outer membrane proteins that bind and transport nickel chelates, vitamin $\mathrm{B}_{12}$, and carbohydrates (Noinaj et al. 2010).

\section{Conclusions}

The current study elucidates the growth-promoting characteristics and complete genetic makeup of Sphingomonas sp. LK11. LK11 produced different types of GAs in pure culture and significantly improved soybean plant growth by altering endogenous hormone levels. Similarly, sequencing and analysis of the LK11 genome support its role as a plant growth-promoting bacterium, prompting further research. Complete genome sequencing confirmed the presence of genes that are involved in plant growthpromoting traits; these include phosphate solubilization and $\mathrm{H}_{2} \mathrm{~S}$ synthesis, which can improve the growth of associated plants. Moreover, biosynthesis pathways of trehalose and glycine betaine were found in the LK11 genome. A total of 8507 genes were identified in the Sphingomonas spp. pan-genome and 1356 orthologous genes were found to comprise the core genome. Utilization of this remarkably versatile PGPB may be an important eco-friendly alternative in improving phytoremediation strategies and crop growth under extreme environmental conditions.

\section{Nucleotide sequence accession numbers}

The assembled and annotated sequences of LK11 (one chromosome and two plasmids) were deposited in GenBank with accession numbers CP013916-CP013918. The information was also submitted to the Genomes Online Database (Gs0118031). The strain was deposited in the International Collection of Microorganisms from Plants (ICMP) under the accession number ICMP 21288.

Acknowledgements This work was financially supported by the National Research Foundation of Korea (NRF), Ministry of Science, ICT and Future Planning through the Basic Science Research Program (2014R1A1A1004918) and the Oman Research Council (ORG/ EBR/15/007).

\section{Compliance with ethical standards}

Conflict of interest The authors declare that they have no conflict of interest.

Open Access This article is distributed under the terms of the Creative Commons Attribution 4.0 International License (http://creativeco mmons.org/licenses/by/4.0/), which permits unrestricted use, distribution, and reproduction in any medium, provided you give appropriate credit to the original author(s) and the source, provide a link to the Creative Commons license, and indicate if changes were made.

\section{References}

Achal V, Savant VV, Reddy MS (2007) Phosphate solubilization by a wild type strain and UV-induced mutants of Aspergillus 
tubingensis. Soil Biol Biochem 39:695-699. https://doi. org/10.1016/j.soilbio.2006.09.003

Adekambi T, Butler RW, Hanrahan F, Delcher AL, Drancourt M, Shinnick TM (2011) Core gene set as the basis of multilocus sequence analysis of the subclass. Actinobacteridae Plos One 6:e14792. https://doi.org/10.1371/journal.pone.0014792

Alikhan N-F, Petty NK, Ben Zakour NL, Beatson SA (2011) BLAST Ring Image Generator (BRIG): simple prokaryote genome comparisons. Bmc Genom 12:1-10. https://doi. org/10.1186/1471-2164-12-402

Angiuoli SV, Gussman A, Klimke W, Cochrane G, Field D, Garrity G, Kodira CD, Kyrpides N, Madupu R, Markowitz V, Tatusova T, Thomson N, White O (2008) Toward an online repository of Standard Operating Procedures (SOPs) for (Meta) genomic annotation. OMICS 12:137-141. https://doi.org/10.1089/ omi.2008.0017

Asaf S, Khan AL, Khan MA, Imran QM, Yun BW, Lee IJ (2017a) Osmoprotective functions conferred to soybean plants via inoculation with Sphingomonas sp. LK11 and exogenous trehalose. Microbiol Res 205:135-145. https://doi.org/10.1016/j.micre s.2017.08.009

Asaf S, Khan MA, Khan AL, Waqas M, Shahzad R, Kim A-Y, Kang S-M, Lee I-J (2017b) Bacterial endophytes from arid land plants regulate endogenous hormone content and promote growth in crop plants: an example of Sphingomonas sp. and Serratia marcescens. J Plant Interact 12:31-38

Atzorn R, Crozier A, Wheeler C, Sandberg G (1988) Production of gibberellins and indole-3-acetic acid by Rhizobium phaseoli in relation to nodulation of Phaseolus vulgaris roots. Planta 175:532-538

Aziz RK, Bartels D, Best AA, DeJongh M, Disz T, Edwards RA, Formsma K, Gerdes S, Glass EM, Kubal M, Meyer F, Olsen GJ, Olson R, Osterman AL, Overbeek RA, McNeil LK, Paarmann D, Paczian T, Parrello B, Pusch GD, Reich C, Stevens R, Vassieva O, Vonstein V, Wilke A, Zagnitko O (2008a) The RAST server: Rapid annotations using subsystems technology. BMC Genom. https://doi.org/10.1186/1471-2164-9-75

Aziz RK, Bartels D, Best AA, DeJongh M, Disz T, Edwards RA, Formsma K, Gerdes S, Glass EM, Kubal M, Meyer F, Olsen GJ, Olson R, Osterman AL, Overbeek RA, McNeil LK, Paarmann D, Paczian T, Parrello B, Pusch GD, Reich C, Stevens R, Vassieva O, Vonstein V, Wilke A, Zagnitko O (2008b) The RAST server: rapid annotations using subsystems technology. Bmc Genom 9:1-15. https://doi.org/10.1186/1471-2164-9-75

Bach E, Seger GDD, Fernandes GD, Lisboa BB, Passaglia LMP (2016) Evaluation of biological control and rhizosphere competence of plant growth promoting bacteria. Appl Soil Ecol 99:141-149. https://doi.org/10.1016/j.apsoil.2015.11.002

Bai NL, Wang S, Abuduaini R, Zhu XF, Zhao YH (2016) Isolation and characterization of Sphingomonas sp Y2 capable of high-efficiency degradation of nonylphenol polyethoxylates in wastewater. Environ Sci Pollut R 23:12019-12029. https://doi. org/10.1007/s11356-016-6413-y

Basak BB, Biswas DR (2009) Influence of potassium solubilizing microorganism (Bacillus mucilaginosus) and waste mica on potassium uptake dynamics by sudan grass (Sorghum vulgare Pers.) grown under two. Alfisols Plant Soil 317:235-255. https ://doi.org/10.1007/s11104-008-9805-z

Bastián F, Cohen A, Piccoli P, Luna V, Bottini R, Baraldi R (1998) Production of indole-3-acetic acid and gibberellins A1 and A3 by Acetobacter diazotrophicus and Herbaspirillum seropedicae in chemically-defined culture media. Plant Growth Regul 24:7-11

Beattie GA, Lindow SE (1999) Bacterial colonization of leaves: a spectrum of strategies. Phytopathology 89:353-359. https://doi. org/10.1094/phyto.1999.89.5.353
Blom J, Albaum SP, Doppmeier D, Pühler A, Vorhölter F-J, Zakrzewski M, Goesmann A (2009) EDGAR: a software framework for the comparative analysis of prokaryotic genomes. BMC Bioinform 10:1-14. https://doi.org/10.1186/1471-2105-10-154

Brettin T, Davis JJ, Disz T, Edwards RA, Gerdes S, Olsen GJ, Olson R, Overbeek R, Parrello B, Pusch GD, Shukla M, Thomason JA, Stevens R, Vonstein V, Wattam AR, Xia FF (2015) RASTtk: a modular and extensible implementation of the RAST algorithm for building custom annotation pipelines and annotating batches of genomes. Sci Rep. https://doi.org/10.1038/ Srep08365

Busse HJ, Denner EBM, Buczolits S, Salkinoja-Salonen M, Bennasar A, Kampfer P (2003) Sphingomonas aurantiaca sp nov., Sphingomonas aerolata sp nov and Sphingomonas faeni sp nov., airand dustborne and Antarctic, orange-pigmented, psychrotolerant bacteria, and emended description of the genus Sphingomonas. Int J Syst Evol Micr 53:1253-1260. https://doi.org/10.1099/ ijs.0.02461-0

Cabiscol E, Tamarit J, Ros J (2000) Oxidative stress in bacteria and protein damage by reactive oxygen species. Int Microbiol 3:3-8

Cerny-Koenig T, Faust J, Rajapakse N (2005) Role of gibberellin A4 and gibberellin biosynthesis inhibitors on flowering and stem elongation in Petunia under modified light environments. HortScience 40:134-137

Chan KG, Yin WF, Lim YL (2014) Complete genome sequence of Pseudomonas aeruginosa strain YL84, a quorum-sensing strain isolated from compost. Genome Announc. https://doi. org/10.1128/genomeA.00246-14

de Werra P, Pechy-Tarr M, Keel C, Maurhofer M (2009) Role of gluconic acid production in the regulation of biocontrol traits of Pseudomonas fluorescens CHA0. Appl Environ Microb 75:4162-4174. https://doi.org/10.1128/Aem.00295-09

Diels L, Dong QH, Vanderlelie D, Baeyens W, Mergeay M (1995) The Czc operon of alcaligenes-eutrophus Ch34-from resistance mechanism to the removal of heavy-metals. J Ind Microbiol 14:142-153. https://doi.org/10.1007/Bf01569896

Dodd IC, Zinovkina NY, Safronova VI, Belimov AA (2010) Rhizobacterial mediation of plant hormone status. Ann Appl Biol 157:361-379. https://doi.org/10.1111/j.1744-7348.2010.00439.x

Dooley FD, Nair SP, Ward PD (2013) Increased growth and germination success in plants following hydrogen sulfide administration Nitric. Oxide-Biol Ch 31:S24-S24. https://doi.org/10.1016/j. niox.2013.06.041

Duan J, Jiang W, Cheng ZY, Heikkila JJ, Glick BR (2013) The complete Genome sequence of the plant growth-promoting bacterium Pseudomonas sp UW4. Plos One. https://doi.org/10.1371/journ al.pone.0058640

Dupont CL, Grass G, Rensing C (2011) Copper toxicity and the origin of bacterial resistance-new insights and applications. Metallomics 3:1109-1118. https://doi.org/10.1039/c1mt00107h

Eevers N, Van Hamme JD, Bottos EM, Weyens N, Vangronsveld J (2015) Sphingomonas taxi, isolated from Cucurbita pepo, proves to be a DDE-degrading and plant growth-promoting strain. Genome Announc 3:e00489-00415 https://doi.org/10.1128/ genomeA.00489-15

Epstein W (2003) The roles and regulation of potassium in bacteria Prog. Nucleic Acid Re 75:293-320. https://doi.org/10.1016/ S0079-6603(03)75008-9

Ermolenko DN, Makhatadze GI (2002) Bacterial cold-shock proteins. Cell Mol Life Sci 59:1902-1913. https://doi.org/10.1007/P1000 12513

Farias ME, Revale S, Mancini E, Ordonez O, Turjanski A, Cortez N, Vazquez MP (2011) Genome sequence of sphingomonas sp $\mathrm{S} 17$, isolated from an alkaline, hyperarsenic, and hypersaline volcano-associated lake at high altitude in the argentinean. Puna J Bacteriol 193:3686-3687. https://doi.org/10.1128/Jb.05225-11

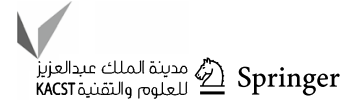


Feng GD, Yang SZ, Wang YH, Zhang XX, Zhao GZ, Deng MR, Zhu HH (2014) Description of a Gram-negative bacterium, Sphingomonas guangdongensis sp nov. Int J Syst Evol Micr 64:16971702. https://doi.org/10.1099/ijs.0.056853-0

Fujiwara H, Soda S, Fujita M, Ike M (2016) Kinetics of bisphenol A degradation by Sphingomonas paucimobilis FJ-4. J Biosci Bioeng. https://doi.org/10.1016/j.jbiosc.2016.02.015

Gai Z, Wang X, Zhang X, Su F, Wang X, Tang H, Tai C, Tao F, Ma C, Xu P (2011a) Genome sequence of Sphingomonas elodea ATCC 31461, a highly productive industrial strain of gellan gum. J Bacteriol 193:7015-7016

Gai ZH, Wang X, Zhang XY, Su F, Wang XY, Tang HZ, Tai C, Tao F, Ma CQ, Xu P (2011b) Genome Sequence of Sphingomonas elodea ATCC 31461, a Highly Productive Industrial Strain of Gellan. Gum J Bacteriol 193:7015-7016. https://doi.org/10.1128/ Jb.06307-11

Garg AK, Kim JK, Owens TG, Ranwala AP, Do Choi Y, Kochian LV, Wu RJ (2002) Trehalose accumulation in rice plants confers high tolerance levels to different abiotic stresses. Proc Natl Acad Sci USA 99:15898-15903. https://doi.org/10.1073/pnas.252637799

Glick BR (1995) The enhancement of plant-growth by free-living bacteria. Can J Microbiol 41:109-117

Gong BN, Wu PX, Huang ZJ, Li YW, Dang Z, Ruan B, Kang CX, Zhu NW (2016) Enhanced degradation of phenol by Sphingomonas sp GY2B with resistance towards suboptimal environment through adsorption on kaolinite. Chemosphere 148:388-394. https://doi.org/10.1016/j.chemosphere.2016.01.003

Gothwal RK, Nigam VK, Mohan MK, Sasmal D, Ghosh P (2008) Screening of nitrogen fixers from rhizospheric bacterial isolates associated with important desert plants. Appl Ecol Env Res 6:101-109

Graumann PL, Marahiel MA (1998) A superfamily of proteins that contain the cold-shock domain. Trends Biochem Sci 23:286-290 doi. https://doi.org/10.1016/S0968-0004(98)01255-9

Gupta M, Kiran S, Gulati A, Singh B, Tewari R (2012) Isolation and identification of phosphate solubilizing bacteria able to enhance the growth and aloin-A biosynthesis of Aloe barbadensis. Miller Microbiol Res 167:358-363. https://doi.org/10.1016/j.micre s. 2012.02 .004

Gupta A, Gopal M, Thomas GV, Manikandan V, Gajewski J, Thomas G, Seshagiri S, Schuster SC, Rajesh P, Gupta R (2014) Whole genome sequencing and analysis of plant growth promoting bacteria isolated from the rhizosphere of plantation crops coconut, cocoa and arecanut. Plos One. 9:e104259. https://doi. org/10.1371/journal.pone.0104259

Gurevich A, Saveliev V, Vyahhi N, Tesler G (2013) QUAST: quality assessment tool for genome assemblies. Bioinformatics 29:10721075. https://doi.org/10.1093/bioinformatics/btt086

Gutiérrez-Mañero FJ, Ramos-Solano B, Probanza A, Mehouachi J, Tadeo R, Talon F M (2001) The plant-growth-promoting rhizobacteria Bacillus pumilus and Bacillus licheniformis produce high amounts of physiologically active gibberellins. Physiol Plant 111:206-211

Hallmann J, QuadtHallmann A, Mahaffee WF, Kloepper JW (1997) Bacterial endophytes in agricultural crops. Can J Microbiol 43:895-914

Halo BA, Khan AL, Waqas M, Al-Harrasi A, Hussain J, Ali L, Adnan M, Lee I-J (2015) Endophytic bacteria (Sphingomonas sp. LK11) and gibberellin can improve Solanum lycopersicum growth and oxidative stress under salinity. J Plant Interac 10:117-125

HammondKosack KE, Jones JDG (1996) Resistance gene-dependent plant defense responses. Plant Cell 8:1773-1791 doi. https://doi. org/10.1105/tpc.8.10.1773

Huang J, Huang Z, Zhang ZD, He LY, Sheng XF (2014) Sphingomonas yantingensis sp nov., a mineral-weathering bacterium isolated from purplish paddy soil. Int J Syst Evol Micr 64:1030-1035. https://doi.org/10.1099/ijs.0.055954-0

Huy H, Jin L, Lee KC, Kim SG, Lee JS, Ahn CY, Oh HM (2014) Sphingomonas daechungensis sp nov., isolated from sediment of a eutrophic reservoir. Int J Syst Evol Micr 64:1412-1418. https ://doi.org/10.1099/ijs.0.054510-0

Iqbal U, Jamil N, Ali I, Hasnain S (2010) Effect of zinc-phosphatesolubilizing bacterial isolates on growth of Vigna radiata. Ann Microbiol 60:243-248. https://doi.org/10.1007/s1321 3-010-0033-4

Ji GY, Silver S (1995) Bacterial-resistance mechanisms for heavy-metals of environmental. Concern J Ind Microbiol 14:61-75 https:// doi.org/10.1007/Bf01569887

Kang SM, Joo GJ, Hamayun M, Na CI, Shin DH, Kim HY, Hong JK, Lee IJ (2009) Gibberellin production and phosphate solubilization by newly isolated strain of Acinetobacter calcoaceticus and its effect on plant growth. Biotechnol Lett 31:277-281. https:// doi.org/10.1007/s10529-008-9867-2

Kang S-M, Radhakrishnan R, Khan AL, Kim M-J, Park J-M, Kim B-R, Shin D-H, Lee I-J (2014) Gibberellin secreting rhizobacterium, Pseudomonas putida H-2-3 modulates the hormonal and stress physiology of soybean to improve the plant growth under saline and drought conditions. Plant Physiol Biochem 84:115-124

Kang S-M, Asaf S, Kim S-J, Yun B-W, Lee I-J (2016) Complete genome sequence of plant growth-promoting bacterium Leifsonia xyli SE134, a possible gibberellin and auxin producer. $\mathbf{J}$ Biotechnol 239:34-38

Kang S-M, Waqas M, Hamayun M, Asaf S, Khan AL, Kim A-Y, Park Y-G, Lee I-J (2017) Gibberellins and indole-3-acetic acid producing rhizospheric bacterium Leifsonia xyli SE134 mitigates the adverse effects of copper-mediated stress on tomato. J Plant Interac 12:373-380

Kera Y, Abe K, Kasai D, Fukuda M, Takahashi S (2016) Draft genome sequences of Sphingobium sp. strain TCM1 and Sphingomonas sp. strain TDK1, haloalkyl phosphate flame retardant-and plasticizer-degrading bacteria. Genome Announc 4:e00668-00616

Khan AL, Waqas M, Kang S-M, Al-Harrasi A, Hussain J, Al-Rawahi A, Al-Khiziri S, Ullah I, Ali L, Jung H-Y (2014) Bacterial endophyte Sphingomonas sp. LK11 produces gibberellins and IAA and promotes tomato plant growth. J Microbiol 52:689-695

Khan AL, Hussain J, Al-Harrasi A, Al-Rawahi A, Lee I-J (2015) Endophytic fungi: resource for gibberellins and crop abiotic stress resistance. Crit Rev Biotechnol 35:62-74

Khan AL, Al-Harrasi A, Al-Rawahi A, Al-Farsi Z, Al-Mamari A, Waqas M, Asaf S, Elyassi A, Mabood F, Shin JH, Lee IJ (2016a) Endophytic fungi from frankincense tree improves host growth and produces extracellular enzymes and indole acetic acid. Plos One 11:e0158207. https://doi.org/10.1371/journal.pone.0158207

Khan AL, Ullah I, Hussain J, Kang SM, Al-Harrasi A, Al-Rawahi A, Lee IJ (2016b) Regulations of essential amino acids and proteomics of bacterial endophytes S phingomonas sp. L k11 during cadmium uptake. Environ Toxicol 31:887-896

Khan AL, Waqas M, Asaf S, Kamran M, Shahzad R, Bilal S, Khan MA, Kang S-M, Kim Y-H, Yun B-W (2017) Plant growth-promoting endophyte Sphingomonas sp. LK11 alleviates salinity stress in Solanum pimpinellifolium. Environ Exp Botany 133:58-69

Kim SJ, Moon JY, Lim JM, Ahn JH, Weon HY, Ahn TY, Kwon SW (2014) Sphingomonas aerophila sp nov and Sphingomonas naasensis sp nov., isolated from air and soil respectively. Int J Syst Evol Micr 64:926-932. https://doi.org/10.1099/ijs.0.05526 9-0

Kumari R, Subudhi S, Suar M, Dhingra G, Raina V, Dogra C, Lal S, van der Meer JR, Holliger C, Lal R (2002) Cloning and characterization of lin genes responsible for the degradation of hexachlorocyclohexane isomers by Sphingomonas paucimobilis 
strain B90. Appl Environ Microb 68:6021-6028. https://doi. org/10.1128/Aem.68.12.6021-6028.2002

Kunito T, Kusano T, Oyaizu H, Senoo K, Kanazawa S, Matsumoto S (1996) Cloning and sequence analysis of czc genes in Alcaligenes sp strain CT14. Biosci Biotech Bioch 60:699-704

Kwak MJ, Jeong H, Madhaiyan M, Lee Y, Sa TM, Oh TK, Kim JF (2014) Genome information of Methylobacterium oryzae, a plant-probiotic methylotroph in the phyllosphere. Plos One 9:e106704. https://doi.org/10.1371/journal.pone.0106704

Lamark T, Rokenes TP, McDougall J, Strom AR (1996) The complex bet promoters of Escherichia coli: regulation by oxygen (ArcA), choline (BetI), and osmotic stress. J bacteriol 178:1655-1662

Lee I-J, Foster KR, Morgan PW (1998) Photoperiod control of gibberellin levels and flowering in sorghum. Plant Physiol 116:1003-1011

Leekitcharoenphon P, Lukjancenko O, Friis C, Aarestrup FM, Ussery DW (2012) Genomic variation in Salmonella enterica core genes for epidemiological typing. BMC Genom 13:88. https://doi. org/10.1186/1471-2164-13-88

Lejon DPH, Nowak V, Bouko S, Pascault N, Mougel C, Martins JMF, Ranjard L (2007) Fingerprinting and diversity of bacterial copA genes in response to soil types, soil organic status and copper contamination Fems. Microbiol Ecol 61:424-437. https://doi.org /10.1111/j.1574-6941.2007.00365.x

Li H, Feng Z-m, Sun Y-j, Zhou W-l, Jiao X, Zhu H (2016) Draft genome sequence of Sphingomonas sp. WG, a Welan Gumproducing strain. Genome Announc 4:e01709-01715

Liesegang H, Lemke K, Siddiqui R, Schlegel H (1993) Characterization of the inducible nickel and cobalt resistance determinant cnr from pMOL28 of Alcaligenes eutrophus CH34. J Bacteriol 175:767-778

Liu SS, Guo CL, Liang XJ, Wu FJ, Dang Z (2016) Nonionic surfactants induced changes in cell characteristics and phenanthrene degradation ability of Sphingomonas sp. GY2B Ecotox Environ Safe 129:210-218. https://doi.org/10.1016/j.ecoenv.2016.03.035

Lushchak VI (2001) Oxidative stress and mechanisms of protection against it in bacteria. Biochemistry (Moscow) 66:476-489. https ://doi.org/10.1023/A:1010294415625

Ma Y, Wang X, Nie X, Zhang Z, Yang Z, Nie C, Tang H (2016) Microbial degradation of chlorogenic acid by a Sphingomonas sp. strain. Appl Biochem Biotechnol. https://doi.org/10.1007/s1201 0-016-2071-2

Magnani D, Solioz M (2007) How bacteria handle copper. In: Nies DH, Silver S (eds) Molecular microbiology of heavy metals. Springer Berlin Heidelberg, Berlin, Heidelberg, pp 259-285. https://doi. org/10.1007/7171_2006_081

Manickam N, Bajaj A, Saini HS, Shanker R (2012) Surfactant mediated enhanced biodegradation of hexachlorocyclohexane $(\mathrm{HCH})$ isomers by Sphingomonas sp NM. Biodegradation 23(05):673-682. https://doi.org/10.1007/s10532-012-9543-z

Markowitz VM, Chen IMA, Palaniappan K, Chu K, Szeto E, Grechkin Y, Ratner A, Jacob B, Huang J, Williams P, Huntemann M, Anderson I, Mavromatis K, Ivanova NN, Kyrpides NC (2012) IMG: the integrated microbial genomes database and comparative analysis system. Nucleic Acids Res 40:D115-D122. https:// doi.org/10.1093/nar/gkr1044

Mellano MA, Cooksey DA (1988) Nucleotide sequence and organization of copper resistance genes from Pseudomonas syringae pv tomato. J Bacteriol 170:2879-2883

Miller TR, Delcher AL, Salzberg SL, Saunders E, Detter JC, Halden RU (2010) Genome sequence of the dioxin-mineralizing bacterium Sphingomonas wittichii RW1. J Bacteriol 192:6101-6102

Miteva VI, Sheridan PP, Brenchley JE (2004) Phylogenetic and physiological diversity of microorganisms isolated from a deep Greenland glacier ice core. Appl Environ Microb 70:202-213. https:// doi.org/10.1128/Aem.70.1.202-213.2004
Monchy S, Benotmane MA, Wattiez R, van Aelst S, Auquier V, Borremans $B$, Mergeay $M$, Taghavi $S$, van der Lelie D, Vallaeys $T$ (2006) Transcriptomic and proteomic analyses of the pMOL30encoded copper resistance in Cupriavidus metallidurans strain CH. Microbiology 152(34):1765-1776. https://doi.org/10.1099/ mic. $0.28593-0$

Mulla SI, Wang H, Sun Q, Hu AY, Yu CP (2016) Characterization of triclosan metabolism in Sphingomonas sp strain YL-JM2C. Sci Rep. https://doi.org/10.1038/Srep21965

Nagel R, Peters RJ (2017) Investigating the phylogenetic range of gibberellin biosynthesis in bacteria. Mol Plant-Microbe Interac 30:343-349

Nies DH (1992) Resistance to cadmium, cobalt, zinc, and nickel in Microbes. Plasmid 27:17-28. https://doi.org/10.1016/0147619x(92)90003-S

Nies DH (1995) The cobalt, zinc, and cadmium efflux system czcabc from alcaligenes-eutrophus functions as a cation-proton antiporter in Escherichia-coli. J Bacteriol 177:2707-2712

Nies DH (1999) Microbial heavy-metal resistance. Appl Microbiol Biotechnol 51:730-750

Nies DH, Silver S (1989) Plasmid-determined inducible efflux is responsible for resistance to cadmium, zinc, and cobalt in Alcaligenes eutrophus. J Bacteriol 171:896-900

Noinaj N, Guillier M, Barnard TJ, Buchanan SK (2010) TonB-dependent transporters: regulation, structure, and function. Annu Rev Microbiol 64: 43-60. https://doi.org/10.1146/annurev.micro .112408 .134247

Overbeek R, Olson R, Pusch GD, Olsen GJ, Davis JJ, Disz T, Edwards RA, Gerdes S, Parrello B, Shukla M, Vonstein V, Wattam AR, Xia FF, Stevens R (2014) The SEED and the rapid annotation of microbial genomes using Subsystems Technology (RAST). Nucleic Acids Res 42:D206-D214. https://doi.org/10.1093/nar/ gkt1226

Pan L, Zhou H, Li J, Huang B, Guo J, Zhang X-L, Gao L-C, Xu C, Liu C-T (2016a) Draft genome sequence of Sphingomonas paucimobilis strain LCT-SP1 isolated from the Shenzhou X spacecraft of China. Stand Genomic Sci. https://doi.org/10.1186/s4079 3-016-0136-z

Pan L, Zhou H, Li J, Huang B, Guo J, Zhang XL, Gao LC, Xu C, Liu CT (2016b) Draft genome sequence of Sphingomonas paucimobilis strain LCT-SP1 isolated from the Shenzhou X spacecraft of China. Stand Genomic Sci 11:18

Park HK, Han JH, Kim TS, Joung Y, Cho SH, Kwon SW, Kim SB (2015) Sphingomonas aeria sp nov from indoor air of a pharmaceutical environment Anton Leeuw. Int J G 107:47-53. https:// doi.org/10.1007/s10482-014-0302-5

Peix A, Rivas-Boyero AA, Mateos PF, Rodriguez-Barrueco C, Martinez-Molina E, Velazquez E (2001) Growth promotion of chickpea and barley by a phosphate solubilizing strain of Mesorhizobium mediterraneum under growth chamber conditions. Soil Biol Biochem 33:103-110. https://doi.org/10.1016/S0038 -0717(00)00120-6

Petkau A, Stuart-Edwards M, Stothard P, Van Domselaar G (2010) Interactive microbial genome visualization with GView. Bioinformatics 26:3125-3126. https://doi.org/10.1093/bioinforma tics/btq588

Phadtare S (2004) Recent developments in bacterial cold-shock response. Curr Issues Mol Biol 6:125-136

Piao AL, Feng XM, Nogi Y, Han L, Li YH, Lv J (2016) Sphingomonas qilianensis sp nov., isolated from surface soil in the permafrost region of qilian mountains. China Curr Microbiol 72:363-369. https://doi.org/10.1007/s00284-015-0957-9

Pilonieta MC, Nagy TA, Jorgensen DR, Detweiler CS (2012) A glycine betaine importer limits Salmonella stress resistance and tissue colonization by reducing trehalose production. Mol Microbiol 84:296-309. https://doi.org/10.1111/j.1365-2958.2012.08022.x

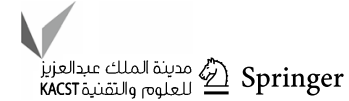


Reddy TB, Thomas AD, Stamatis D, Bertsch J, Isbandi M, Jansson J, Mallajosyula J, Pagani I, Lobos EA, Kyrpides NC (2015) The Genomes OnLine Database (GOLD) v.5: a metadata management system based on a four level (meta)genome project classification. Nucleic Acids Res 43:D1099-D1106. https://doi. org/10.1093/nar/gku950

Reissinger A, Vilich V, Sikora RA (2001) Detection of fungi in planta: effectiveness of surface sterilization methods. Mycol Res 105:563-566 doi. https://doi.org/10.1017/S0953756201003823

Rensing C, Grass G (2003) Escherichia coli mechanisms of copper homeostasis in a changing environment. FEMS Microbiol Rev 27:197-213. https://doi.org/10.1016/S0168-6445(03)00049-4

Rodriguez H, Gonzalez T, Goire I, Bashan Y (2004) Gluconic acid production and phosphate solubilization by the plant growthpromoting bacterium Azospirillum spp. Naturwissenschaften 91:552-555. https://doi.org/10.1007/s00114-004-0566-0

Ryan RP, Germaine K, Franks A, Ryan DJ, Dowling DN (2008) Bacterial endophytes: recent developments and applications Fems. Microbiol Lett 278:1-9. https://doi.org/10.111 1/j.1574-6968.2007.00918.x

Santoyo G, Moreno-Hagelsieb G, Orozco-Mosqueda MD, Glick BR (2016) Plant growth-promoting bacterial endophytes. Microbiol Res 183:92-99. https://doi.org/10.1016/j.micres.2015.11.008

Shahzad R, Khan AL, Bilal S, Asaf S, Lee I-J (2017) Plant growthpromoting endophytic bacteria versus pathogenic infections: an example of Bacillus amyloliquefaciens RWL-1 and Fusarium oxysporum f. sp. lycopersici in tomato. PeerJ 5:e3107

Silver S (1996) Bacterial resistances to toxic metal ions: a review. Gene 179:9-19. https://doi.org/10.1016/S0378-1119(96)00323-X

Silver S, Phung LT (1996) Bacterial heavy metal resistance: New surprises. Annu Rev Microbiol 50:753-789. https://doi.org/10.1146/ annurev.micro.50.1.753

Tabata M, Ohtsubo Y, Ohhata S, Tsuda M, Nagata Y (2013) Complete genome sequence of the $\gamma$-hexachlorocyclohexane-degrading bacterium sphingomonas sp. strain MM-1. Genome Announc 1:e00247-00213. https://doi.org/10.1128/genomeA.00247-13

Tadra-Sfeir MZ, Souza EM, Faoro H, Muller-Santos M, Baura VA, Tuleski TR, Rigo LU, Yates MG, Wassem R, Pedrosa FO, Monteiro RA (2011) Naringenin regulates Expression of genes involved in cell wall synthesis in Herbaspirillum seropedicae. Appl Environ Microb 77:2180-2183. https://doi.org/10.1128/ Aem.02071-10

Tibazarwa C, Wuertz S, Mergeay M, Wyns L, van Der Lelie D (2000) Regulation of the cnr cobalt and nickel resistance determinant of Ralstonia eutropha (Alcaligenes eutrophus) CH34. J Bacteriol 182:1399-1409

Urwin R, Maiden MC (2003) Multi-locus sequence typing: a tool for global epidemiology. Trends Microbiol 11:479-487

Vidyalakshmi R, Paranthaman R, Bhakyaraj R (2009) Sulphur oxidizing bacteria and pulse nutrition: a review world. J Agric Sci 5:270-278

Voloudakis AE, Reignier TM, Cooksey DA (2005) Regulation of resistance to copper in Xanthomonas axonopodis pv vesicatoria.
Appl Environ Microb 71:782-789. https://doi.org/10.1128/ Aem.71.2.782-789.2005

Wang Y, Brown HN, Crowley DE, Szaniszlo PJ (1993) Evidence for direct utilization of a siderophore, ferrioxamine-B, in axenically grown cucumber. Plant Cell Environ 16:579-585. https://doi. org/10.1111/j.1365-3040.1993.tb00906.x

Waqas M, Khan AL, Kamran M, Hamayun M, Kang S-M, Kim Y-H, Lee I-J (2012) Endophytic fungi produce gibberellins and indoleacetic acid and promotes host-plant growth during stress. Molecules 17:10754-10773

Wei GH, Fan LM, Zhu WF, Fu YY, Yu JF, Tang M (2009) Isolation and characterization of the heavy metal resistant bacteria $\mathrm{CCN}$ WRS33-2 isolated from root nodule of Lespedeza cuneata in gold mine tailings in China. J Hazard Mater 162:50-56. https://doi. org/10.1016/j.jhazmat.2008.05.040

Wei S, Wang T, Liu H, Zhang C, Guo J, Wang Q, Liang K, Zhang Z (2015) Sphingomonas hengshuiensis sp. nov., isolated from lake wetland. Int J Syst Evol Microbiol 65:4644-4649. https://doi. org/10.1099/ijsem.0.000626

Wilson D (1995) Endophyte - the evolution of a term, and clarification of its use and definition. Oikos 73:274-276. https://doi. org/10.2307/3545919

Xie JB, Shi HW, Du ZL, Wang TS, Liu XM, Chen SF (2016) Comparative genomic and functional analysis reveal conservation of plant growth promoting traits in Paenibacillus polymyxa and its closely related species. Sci Rep. https://doi.org/10.1038/Srep21329

Xu X, van Lammeren AA, Vermeer E, Vreugdenhil D (1998) The role of gibberellin, abscisic acid, and sucrose in the regulation of potato tuber formation in vitro. Plant Physiol 117:575-584

Yaish MW, Antony I, Glick BR (2015) Isolation and characterization of endophytic plant growth-promoting bacteria from date palm tree (Phoenix dactylifera L.) and their potential role in salinity tolerance. Antonie Van Leeuwenhoek 107:1519-1532. https:// doi.org/10.1007/s10482-015-0445-z

Yang J, Kloepper JW, Ryu CM (2009) Rhizosphere bacteria help plants tolerate abiotic stress. Trends Plant Sci 14:1-4. https:// doi.org/10.1016/j.tplants.2008.10.004

Zeidler D, Zahringer U, Gerber I, Dubery I, Hartung T, Bors W, Hutzler P, Durner J (2004) Innate immunity in Arabidopsis thaliana: Lipopolysaccharides activate nitric oxide synthase (NOS) and induce defense genes. Proc Natl Acad Sci USA 101:1581115816. https://doi.org/10.1073/pnas.0404536101

Zeller T, Klug G (2006) Thioredoxins in bacteria: functions in oxidative stress response and regulation of thioredoxin genes Naturwissenschaften 93:259-266 https://doi.org/10.1007/s0011 4-006-0106-1

Zhao Y, Wu J, Yang J, Sun S, Xiao J, Yu J (2012) PGAP: pan-genomes analysis pipeline. Bioinformatics 28:416-418. https://doi. org/10.1093/bioinformatics/btr655

Zhu X, Wang W, Xu P, Tang H (2016) Complete genome sequence of Sphingomonas sp. strain NIC1, an efficient nicotine-degrading bacterium. Genome Announc 4:e00666-00616 https://doi. org/10.1128/genomeA.00666-16 